\title{
Emergency Management of an Acute Tension Pneumocephalus Following Ventriculoperitoneal Shunt Surgery for Normal Pressure Hydrocephalus
}

\section{Normal Basınçlı Hidrosefali Nedeniyle Yapulan Ventriküloperitoneal Şant Cerrabisi Sonrası Gelişen Akut Tansiyon Pnömosefali}

Aydın AYDOSELI, Mehmet Osman AKCAKAYA, Yavuz ARAS, Osman BOYALI, Omer Faruk UNAL

Istanbul University, Istanbul Faculty of Medicine, Department of Neurosurgery, Istanbul, Turkey

Corresponding Author: Mehmet Osman AKÇAKAYA / E-mail: moakcakaya@gmail.com

\begin{abstract}
Tension pneumocephalus is a rare and life threatening complication of intracranial surgical procedures, and requires immediate recognition and surgical intervention. Tension pneumocephalus following ventriculoperitoneal shunt surgery is extremely rare and commonly seen as a delayed complication. To our knowledge, early postoperative tension pneumocephalus after shunt surgery was reported only in one other publication. We present a case of acute tension pneumocephalus following ventriculoperitoneal shunt surgery for normal pressure hydrocephalus, which was managed well with close neurological follow-up and rapid surgical intervention. The use of the portable CT scanner in this case saved significant time, without the transport of the patient to the radiology unit, made early surgical intervention possible, and prevented morbidity and mortality.
\end{abstract}

KEYWORDS: Tension pneumocephalus, Ventriculoperitoneal shunt surgery, Portable CT scanner, Emergency surgery

öz

Tansiyon pnömosefali, intrakranyal cerrahi girişimler sonrası nadir gelişen ancak hayatı tehdit eden bir patolojidir. Bu nedenle erken tanı konulması ve acil cerrahi müdahale edilmesi gerekir. Şant cerrahisi sonrası gelişen tansiyon pnömosefali daha da nadirdir ve genelde geç dönemde ortaya çıkmaktadır. Bildiğimiz kadarıyla literatürde sadece bir tane ameliyat sonrası erken dönemde gelişen akut pnömosefali olgusu mevcuttur. Bu yazıda normal basınçlı hidrosefali nedeniyle yapılan ventriküloperitoneal şant cerrahisini takiben gelişen, yakın nörolojik muayene ve acil cerrahi müdahale ile uygun şekilde yönetilen bir akut tansiyon pnömosefali olgusu sunulmaktadır. Bu olguda ameliyathanemizde bulunan mobil BT cihazının kullanılması hastanın radyoloji birimine transportunu gerektirmeden erken tanı konulmasını ve buna bağlı olarak erken cerrahi müdahaleyi olanaklı kılmış, morbidite ve mortalite gelişmesini engellemiştir.

ANAHTAR SÖZCÜKLER:Tansiyon pnömosefali, Ventriküloperitoneal şant cerrahisi, Mobil BT cihazı, Acil cerrahi

\section{INTRODUCTION}

Pneumocephalus is defined as the presence of air within the calvarium. The air may be in epidural, subdural, intracisternal, intraventricular spaces or within the operative cavity (3). This phenomenon is strongly associated with head trauma, but it is also a common complication of intracranial surgical procedures $(1,5,8,11)$. Tension pneumocephalus is a lifethreatening neurosurgical emergency that needs immediate surgical intervention (6). It is very rare after cerebrospinal fluid (CSF) divertion procedures and usually seen in a delayed fashion $(1,2,7,8,10,12,13)$.

We report a case of acute tension pneumocephalus following ventriculoperitoneal (VP) shunt surgery for normal pressure hydrocephalus.

\section{CASE REPORT}

A 75-year-old man presented at the neurology department with gait disturbance, urinary incontinance and mild dementia. His symptoms had been continuing for 6 months and the gait disturbance was especially progressive. No other risk factors were found in the patient's history or physical examination. Neurological examination revealed an unsteady and slow gait. There were no other characteristics in his neurological examination. Cognitive functions were assessed with mini-mental state examination (MMSE). MMSE score of $22 / 30$ (time orientation $4 / 5$, place orientation $4 / 5$, recall $0 / 3$, attention-calculation $3 / 5$, complex commands $5 / 6$ ) indicated a cognitive impairment.

The magnetic resonance imaging (MRI) showed tetraventricular hydrocephalus and mild cortical atrophy. (Figure 1). The Evans ratio was found to be 0,47 . The patient was then referred to our clinic with the diagnosis of normal 
pressure hydrocephalus and a VP shunt procedure was planned. Using a right frontal burr-hole at Kocher's point a shunt system (Delta shunt kit, Level 1.5 Medtronic Inc, Minneapolis, MN, USA) was placed. After the wound closure, an immediate computerized tomography (CT) was performed at the operating theater and the tip of the ventricular cathether was found to be at the frontal horn of the right lateral ventricle (Figure 2). There was no significant event within the first eight hours following the operation. Then a sudden neurological deterioration of the patient was detected.

Severe confusion, disturbance of consciousness (Glasgow coma scale E3M6V4:13) and left hemiparesis of 2/5 level were found in his neurological examination. After airway and oxygen support was supplied, the patient was immediately taken to the operating room, which was the closest place to

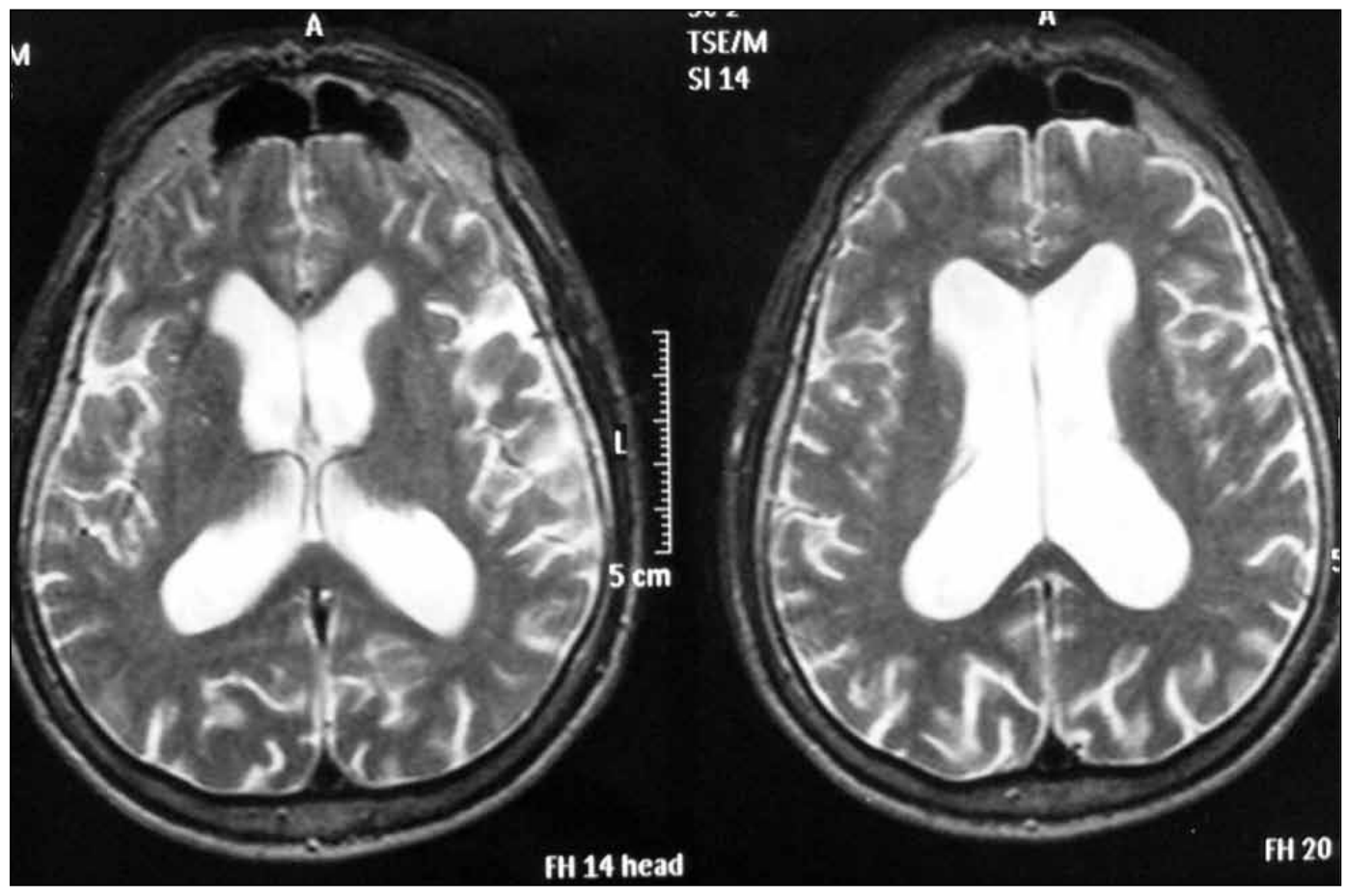

Figure 1: Preoperative MRI demonstrated hydrocephalus with an Evans ratio of 0.47 with accompanying mild cortical atrophy.

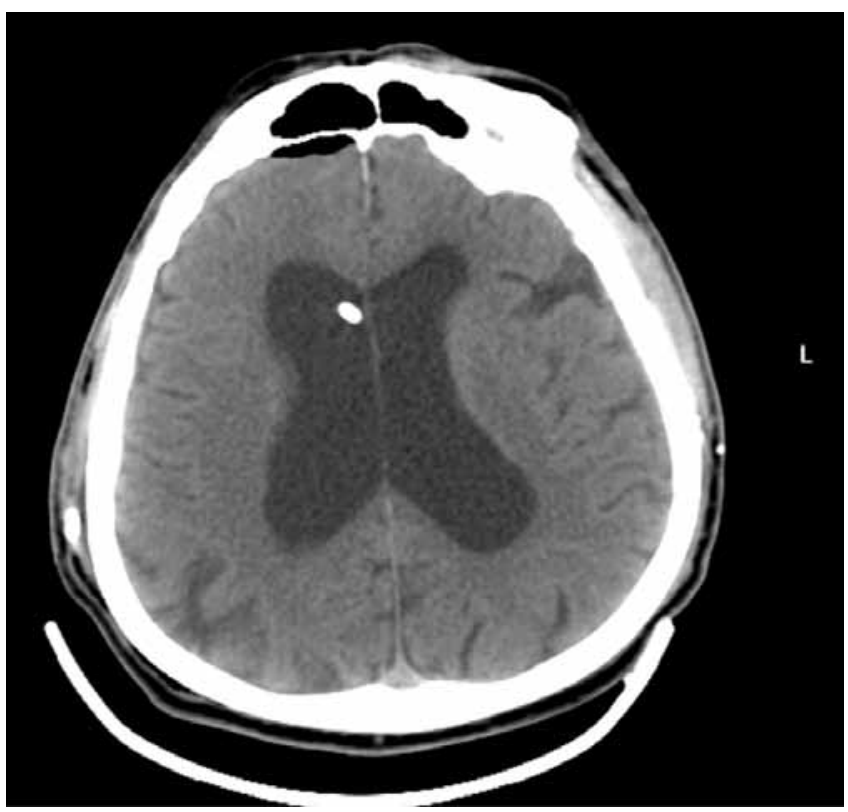

Figure 2: Early postoperative CT scan performed in the operating room showed no significant features other than mild pneumocephalus. Ventricular catheter was in the right frontal horn of the lateral ventricle.

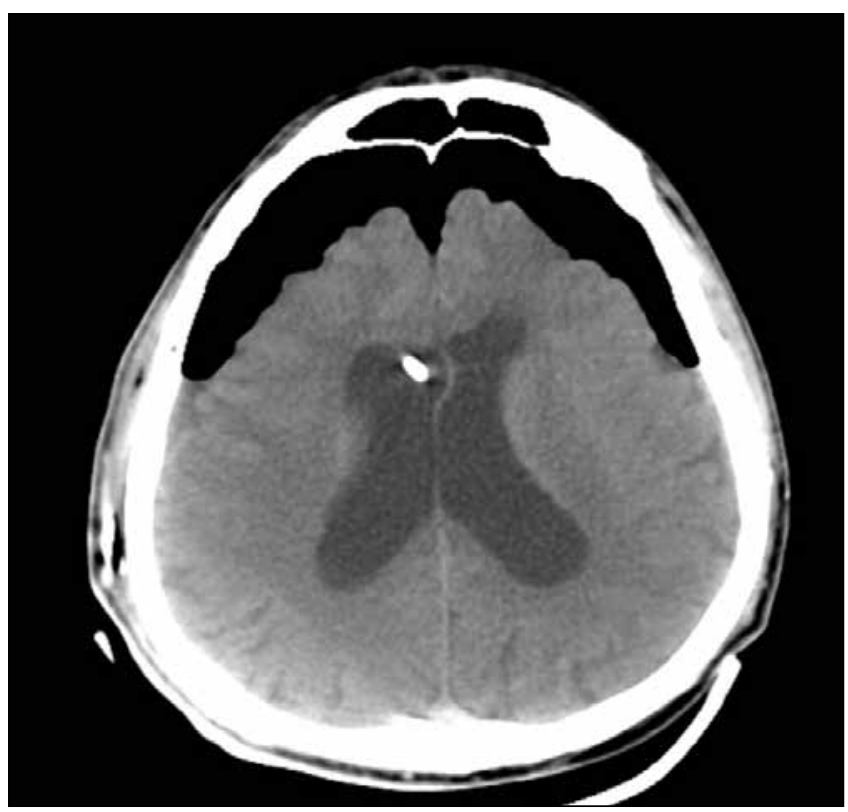

Figure 3: Postoperative CT scan performed after neurological deterioration of the patient. Isolated subdural tension pneumcephalus causing pressure on neural tissue with widening of the interhemispheric space. 


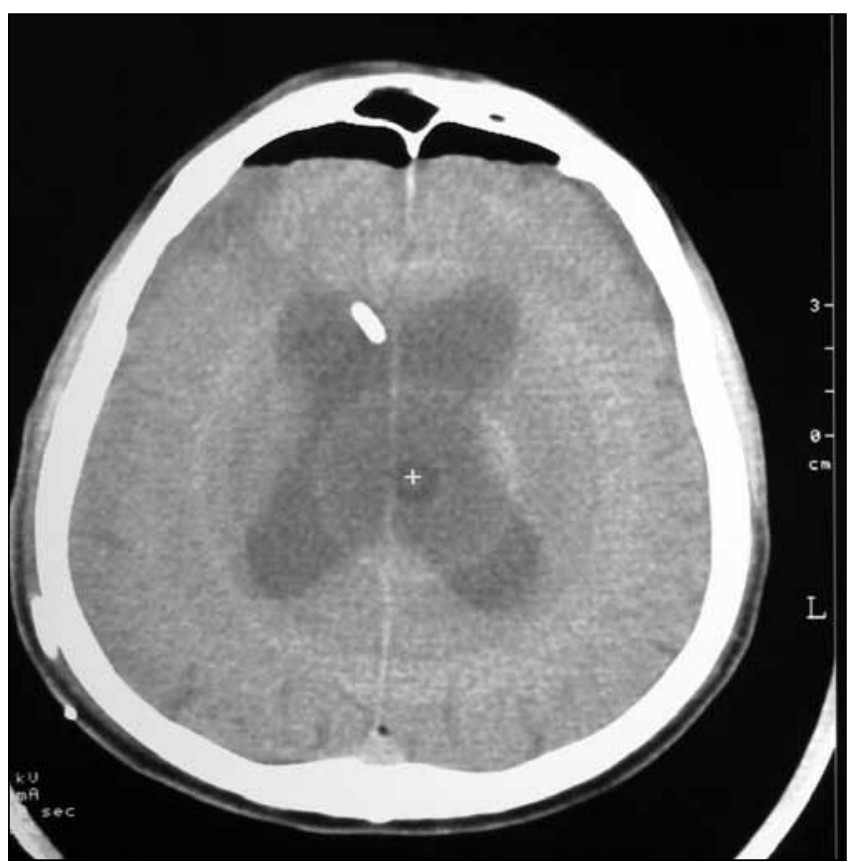

Figure 4: Late control CT scan after the removal of underwater drainage catheter demonstrates the resolution of the air.

obtain a CT scan and to perform a surgical intervention. A CT scan obtained with the portable CT scanner (CereTom, Neuro Logica, Danvers, MA, USA) showed bifrontal subdural tension pneumocephalus (Figure 3). An external ventricular drainage catheter was inserted in the subdural space using a left frontal twist-drill hole and air was removed from the intracranial vault with continuing underwater drainage. The drainage was placed on the contralateral side in order to reduce infection risk. On inspection for air influx a pinhole-like wound defect was found on the ventriculostomy incision and it was sutured using $3 / 0$ prolene sutures. The patient was taken to the intensive care unit and his neurological status improved rapidly. On the next day, patient's neurological examination was completely normal. Control CT scans demonstrated the resolution of the air and the drainage was removed (Figure 4). The patient was discharged from the hospital after ten days of service care with significant improvement of his initial complaints, especially gait disturbance and urinary incontinence.

\section{DISCUSSION}

Pneumocephalus usually occurs after head trauma, skull base fractures, CSF fistulas, intracranial tumors or infections (1). latrogenic pneumocephalus as a result of neurosurgical procedures is a common complication, which generally resolves spontaneously by time.

The incidence of this entity was reported to be as high as 100 $\%$ following supratentorial craniotomies (9). On the other hand tension pneumocephalus is a neurosurgical emergency that requires rapid surgical intervention. It usually presents with headache. If the entrapped air within the calvarium causes pressure or compression on the neural tissue, severe deficits, brainstem compression or even death may ocur. This rare complication is seen approximately in $0.1-0.2 \%$ of all craniotomies (11).

Pneumocephalus as a complication of CSF diversion procedures is rare (13). Tension pneumocephalus following VP shunt surgery is extremely rare, with less than 50 reported cases in the literature $(6,12)$. Most of these cases have presented as a delayed complication of VP shunt surgery. To our knowledge, early postoperative tension pneumocephalus after shunt surgery was reported only in one other publication (1).

Diagnosis is mainly based on clinical examination and computerized tomography (CT) scan. CT scan is the most sensitive diagnostic tool for pneumocephalus. Even small amounts of air such as $0.5 \mathrm{cc}$ can be detected on CT scans (12). Two characterized CT findings were defined by Ishiwata et al. for subdural tension pneumocephalus (4). The "Mt Fuji sign" indicates the presence of subdural air with widening of the interhemispheric space, whereas the air within the cisterns is defined as the "air bubble sign". Only "Mt Fuji sign" was seen in our case and there was no air within the cisterns. There was also no air within the ventricles (Figure 3).

There are two factors that are thought to be responsible for tension pneumocephalus developement. The first one is a decrease of intracranial pressure, due to a shunt system or CSF leakage and the second one is the presence of a craniodural defect that works as a water-valve, allowing air inflow to the intracranial space and preventing outflow (12).

Barada et al. presented a case of an early onset tension pneumocephalus within the subdural space following shunt surgery for normal pressure hydrocephalus, which resembles our case. It is claimed that the moderate cerebral atrophy might have played a role (1). We believe that the most important factor in our case is the wound defect and CSF loss during the ventriculostomy procedure, which obviously was the cause of the pneumocephalus. The duration of the shunt surgery must be as short as possible and CSF leakage during the connection of the shunt system must be avoided in order to prevent a decrease in intracranial pressure and pneumocephalus. Filling of the subdural space on the ventriculostomy site with the irrigation fluid until overflowing might be helpful in the outflow of the air from the intracranial vault and reducing the risk of this rare complication. The shunt valve that was used in this case caused a significant decrease in intracranial pressure and worked as a vacuum system, pulling air through the wound defect. If a programmable valve was chosen, the decrease in the intracranial pressure would be controlled more properly by adjusting the valve pressure at higher levels. Cortical atrophy probably had also an effect on the isolated air collection within the subdural space.

Tension pneumocephalus is a life-threatening pathology and requires immediate surgical intervention. Since the air is in gas form, thermal expansion of the air in hours with body temperature causes tension pneumocephalus. Although 
it is a rare complication of VP shunt surgery, patients must be followed up very closely and clinical manifestations, which can be as mild as a headache or as severe as signs of brainstem herniation, must be detected rapidly. Emergency CT scan must be obtained and immediate drain insertion and continuing underwater drainage must be performed. In our case with close follow-up, the rapid clinical deterioration was immediately detected and the patient was quickly taken to the operating room, where a CT scan was obtained and surgical intervention was performed. We believe that the presence of the portable CT scanner in our operating room, which was originally used for navigation and intraoperative imaging purposes, was also important in this case. In addition to the close neurological monitoring of the patient, the use of the portable CT scanner in this case saved significant time, without transport of the patient to the radiology unit, and made early surgical intervention possible, preventing morbidity and mortality.

In conclusion, proper layered closure of the skin in VP shunt surgery is the most important factor for prevention of this rare complication. Once it occurs, close monitoring of the patient, rapid identification of tension pneumocephalus and immediate surgical intervention is life-saving.

\section{REFERENCES}

1. Barada W, Najjar M, Beydoun A: Early onset tension pneumocephalus following ventriculoperitoneal shunt insertion for normal pressure hydrocephalus: A case report. Clin Neurol Neurosurg 111: 300-302, 2009

2. Czepko R, Morga R, Uhl H: Pneumocephalus after shunt in a patient with hydrocephalus. A case report and review of the literature. Neurol Neurochir Pol 39: 524-530, 2005

3. Garg N, Devi I, Dua R, Arivazhagan A:Tension pneumocephalus following exposure of shunt chamber. Br J Neurosurg 22(1): $121-122,2008$
4. Ishiwata Y, Fujitsu K, Sekino T, Fujino H, Kubokura T, Tsubone $\mathrm{K}$, Kuwabara T: Subdural pneumocephalus following surgery for chronic subdural hematoma. J Neurosurg 68: 58-61, 1988

5. Kawajiri K, Matsuoka Y, Hayazaki K: Brain tumors complicated by pneumocephalus following cerebrospinal fluid shunting: Two case reports. Neurol Med Chir 34(1): 10-14, 1994

6. Monas J, Peak DA: Spontaneous tension pneumocephalus resulting from a scalp fistula in a patient with a remotely placed ventriculoperitoneal shunt. Ann Emerg Med 56: 378-381, 2010

7. Perrin RG, Bernstein M: Tension pneumoventricle after placement of a ventriculoperitoneal shunt: A novel treatment strategy. J Neurosurg 102(2): 386-388, 2005

8. Radhziah S, Lee CK, Ng I: Tension pneumoventricle. J Clin Neurosci 13(8): 881-883, 2006

9. Reasoner DK, Todd M, Scamman FL, Warner DS: The incidence of pneumocephalus after supratentorial craniotomy. Observations on the disappearance of intracranial air. Anesthesiology 80: 1008-1012, 1994

10. Sasani M, Ozer FA, Oktenoglu T: Delayed and isolated intraventricular tension pneumocephalus after shunting for normal pressure hydrocephalus. Neurol India 55(1): 81-82, 2007

11. Sprague A, Poulgrain P: Tension pneumocephalus: $A$ case report and literature review. J Clin Neurosci 6: 418-424, 1999

12. Tugcu B, Tanrıverdi O, Gunaldı O, Baydın S, Postalcı LS, Akdemir $\mathrm{H}$ : Delayed intraventricular tension pneumocephalus due to scalp-ventricle fistula: A very rare complication of shunt surgery. Turk Neurosurg 19: 276-280, 2009

13. Ugarizza LF, Cabezudo JM, Lorenzana LM, Porras LF, GarciaYague LM: Delayed pneumocephalus in shunted patients. Report of three cases and review of the literature. $\mathrm{Br} J$ Neurosurg 15: 161-167, 2001 